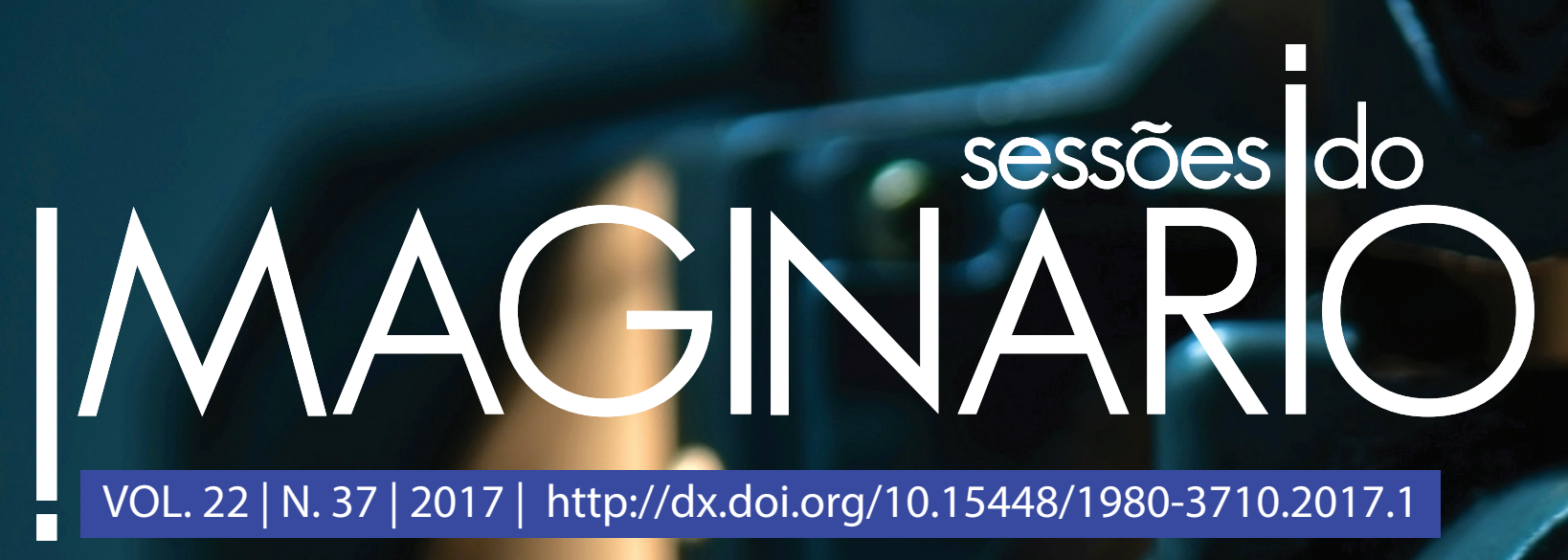

A Comunicação Móvel e Ubíqua do Instagram

Eduardo Campos Pellanda e Melissa Streck
O choque do real em Azul é a cor mais quente

Otacílio Amaral Filho, Sérgio do Espírito Santo Ferreira Júnior e Tarcízio Macedo

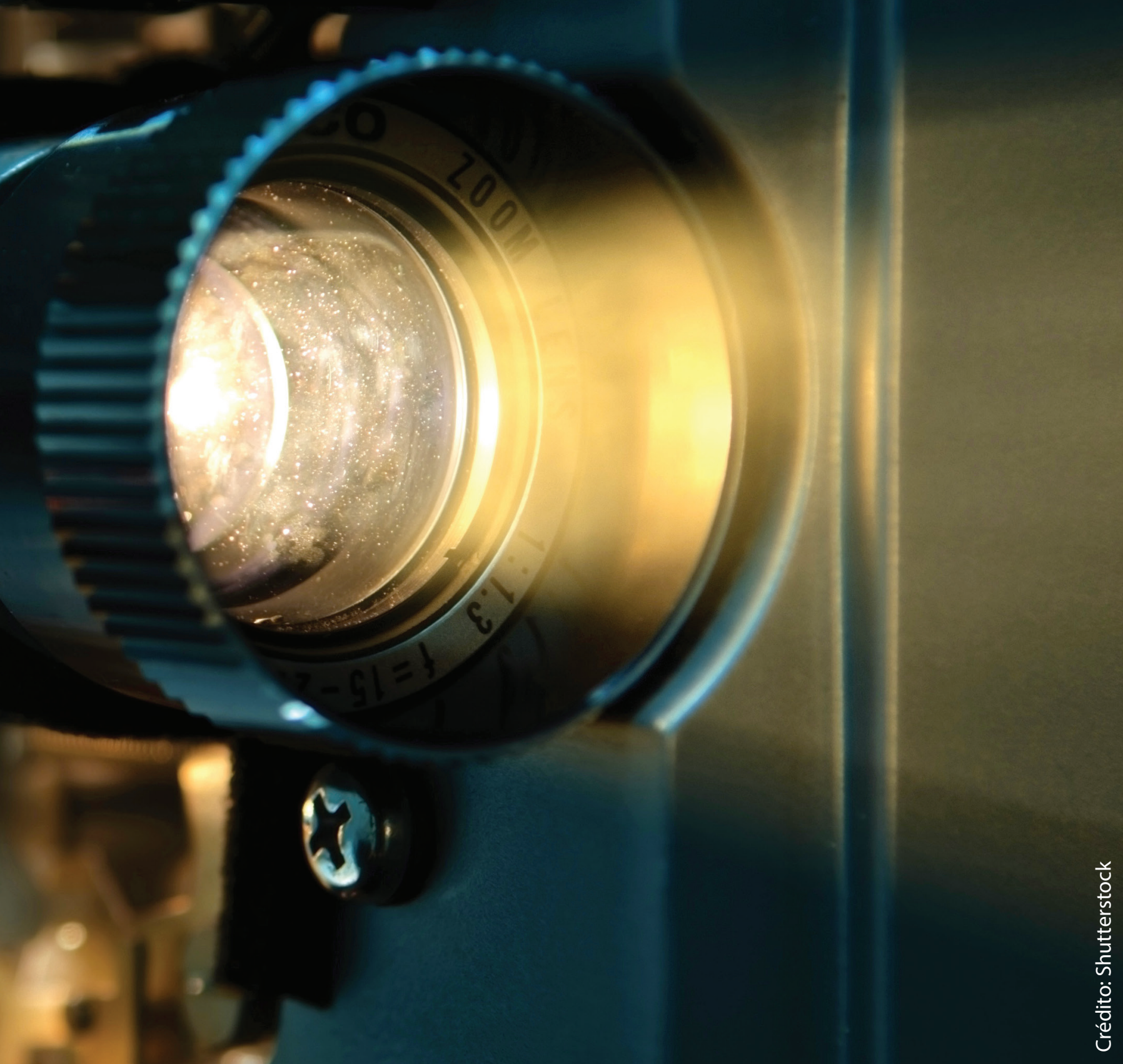

A luta de classes em Que Horas ela Volta?

Mayara Luma Assmar Correia Maia Lobato 


\section{Profanando os corpos: o abjeto nas imagens de Joel-Peter Witkin}

\section{Desecrating the bodies: the abject in Joel-Peter Witkin pictures}

\section{Julio César Sanches'}

\section{Resumo}

Este trabalho apresenta uma série de apontamentos sobre o conceito de abjeto a partir da análise de algumas fotografias produzidas pelo artista visual nova-iorquino Joel-Peter Witkin. Recorrendo ao abjeto como um fenômeno que causa estranhamento, medo e nojo, o artista produz obras que evidenciam uma crítica a determinados valores morais associados ao corpo na cultura contemporânea. Neste artigo, propomos que o corpo abjeto que emerge das imagens de Witkin age como profanador de certos enunciados e representações forjadas nos discursos do corpo belo e saudável.

\section{Palavras-chave}

Abjeto; imagem; profanação.

\section{Abstract}

This research presents some notes about the conception of abject from the analysis of some photographs produced by the New York visual artist Joel-Peter Witkin. Taking the abject as a phenomenon that causes estrangement, fear and disgust, the artist works production evidenced some criticism toward to moral values associated to the body in contemporary culture. In this paper, it is proposed that the abject body that emerges from Witkin's images acts as a profaner of certain statements and representations forged in the speeches of the beautiful and healthy body.

\section{Keywords}

Abject; image; desecration.

77 PORTO ALEGRE | v. 22 | n. 37 | 2017 | pp. 77-85 


\section{Introdução}

O artista visual nova-iorquino Joel Peter Witkin, nascido em 1939 e ainda atuante no cenário artístico contemporâneo, é conhecido por produzir imagens de corpos em "estado de precariedade". Nessa definição de precariedade utilizada pelo artista estão os corpos torturados, dilacerados, deformados e marginais em suas formas ou atributos. Adepto da estética grotesca, Witkin produziu diferentes ensaios fotográficos que remetem também à estética do abjeto. Esta última palavra possui toda uma linhagem conceitual no seio da filosofia e da psicanálise contemporâneas, cujas reverberações serão analisadas a seguir, procurando entender de que modo elas aparecem na obra de Witkin como um dos principais tópicos de seu trabalho.

Sendo o corpo abjeto uma marca importante na obra de Joel-Peter Witkin, portanto, para fazer uma análise de suas implicações, devemos apresentar alguns elementos do conceito de abjeto e, a seguir, examinar como ele se manifesta nas imagens aqui focalizadas. Pretendemos destacar, no trabalho de Witkin, certa retórica que visa profanar algumas características visuais do corpo canônico vigente na contemporaneidade, ferindo seus contornos e questionando sua hegemonia.

\section{(In) definições do conceito de abjeto}

Afinal, o que é o abjeto? Perguntas como essa sugerem o teor misterioso e pouco conhecido desse conceito complexo, que se ramificou nas ciências humanas do último século. Apesar dessas dificuldades, o conceito de abjeto pode abrir um horizonte de compreensão tanto das características da obra de Joel-Peter Witkin como das formas de se vivenciar o corpo na contemporanei- dade. $\mathrm{O}$ abjeto é algo que nos atormenta porque ultrapassa os limites, subverte a lei e causa asco. $\mathrm{O}$ imundo, o sujo e o repugnante são as expressões mais habituais do abjeto em nossa vida cotidiana.

Atuando nos processos que envolvem o corpo e as noções de sujeira, o abjeto se manifesta como fenômeno capaz de problematizar as normas ocidentais de higiene. A utilização de caracteres demarcados como abjetos, seja na arte ou em outros âmbitos culturais, pode indicar de que modo os fluidos corporais foram regulados nos diversos momentos históricos, e como o lugar do abjeto foi sendo desenvolvido pelas práticas e discursos regulatórios da cultura ocidental.

Entre os autores modernos que se dedicaram a trabalhar tanto o conceito como algumas manifestações do abjeto, destaca-se a psicanalista francesa Julia Kristeva. Em seu livro Poderes de la perversión, por exemplo, ela aposta na existência de uma estrutura psíquica que organiza o abjeto e considera que isso seria característico da cultura ocidental. Kristeva (1989) entende que a estrutura da abjeção pode ser pensada como um "mecanismo de produção do Eu".

$\mathrm{Na}$ argumentação de Kristeva, esse mecanismo de produção do Eu se estabelece no processo de formação de fronteiras que demarcam o lugar do Eu e do Outro, do interno e do externo, dando à luz as noções de corpo individual e fechado. Além disso, contribui para a construção dos discursos sobre certos organismos e fenômenos capazes de contaminar a estabilidade orgânica do corpo, que também é psíquica nessa abordagem.

De acordo com essa interpretação psicanalítica, portanto, o abjeto é paradoxal: ele produz, ao mesmo tempo, uma força atrativa e outra repulsiva. Esse paradoxo se manifesta em um conjunto de ações, discursos, prá- ticas e sentimentos que organizam a separação entre o humano e tudo aquilo que pode vir a 'contaminar' a humanidade. Por isso, para Kristeva, o abjeto opera como uma "política". Essa noção coloca em cena um conjunto de tabus e interdições que articulam as posições do sujeito e as relações entre os corpos. Nesse sentido, a "política da abjeção" a que se refere a psicanalista atua diretamente sobre o corpo, seja ele vivo ou morto.

Um exemplo significativo, que explora esse entendimento do abjeto como uma "política", desenvolvido por Kristeva, é a relação entre o corpo vivo e o cadáver. Os rituais culturais que visam a separação do cadáver da esfera pública e o sistema de inumação, por exemplo, forjam rituais estruturados por discursividades que reiteram a ideia do cadáver enquanto corpo intocável, organismo suscetível de intensa contaminação orgânica e psíquica. "O cadáver - visto sem Deus e fora da ciência - é o cúmulo da abjeção. É a morte infestando a vida"² (Kristeva, 1989, p. 11).

De fato, o cadáver é a imagem por excelência da contaminação que caracteriza o abjeto, pois o corpo morto expõe tudo aquilo que foi expulso das imagens mais tranquilizadoras do humano. Nós, seres viventes, construímos o que somos com base em certa definição implícita do que significa ser alguém: projetamos a imagem de um corpo fechado, higienizado e coberto por uma pele sem fissuras. Ou seja, o cadáver materializa o abjeto por ser a antítese da imagem do corpo humano vivo e estabilizado pelos mecanismos regulatórios da cultura ocidental.

O abjeto é, portanto, um fenômeno desestabilizador: faz ver a violência que afeta o corpo, o abjeto revela a obscenidade do interior do corpo com seus órgãos e suas vísceras. Em outras palavras: a abjeção provocada 
por um cadáver, por exemplo, é constituída pelo processo de degeneração da carne pela decadência, por fazer ver aquilo que é rejeitado pelas normas culturais.

$\mathrm{Na}$ esteira do pensamento ocidental sobre o abjeto, o filósofo francês Georges Bataille (2013) diz que a separação radical entre o corpo do morto e os viventes construiu o fenômeno da interdição da morte. Essa interdição se constitui a partir da retirada do cadáver da esfera pública. Esse fenômeno de interdição elabora um conjunto de condutas específicas que giram em torno do cadáver. Para alguns, ele pode ganhar um valor sagrado e afetivo quando se trata do corpo de algum familiar, por exemplo, mas também se torna símbolo da destruição que contamina o humano por ser abjeto. Em suma, a recusa, o medo e o nojo provocado pelo cadáver é o efeito do interdito, no entendimento de Bataille, ou é a censura da política da abjeção aludida por Kristeva.

Bataille apresenta a ideia de que o interdito estabelecido em relação aos cadáveres forjou também o sentimento de um tempo futuro: o tempo em que morreremos. É por isso que o cadáver atormentaria intimamente o humano, de acordo com o filósofo. Aqui identificamos outro ponto de confluência entre os escritos de Julia Kristeva e os de Georges Bataille. Para este último, por exemplo, a angústia provocada pela imagem do cadáver produz o valor simbólico que gira em torno dele e desenvolve a rejeição da visão do corpo morto. Essa rejeição do cadáver também é significativa no pensamento de Kristeva porque o medo da contaminação orgânica e psíquica provocada pelo cadáver se materializa como abjeto.

Para cada um daqueles que fascina, o cadáver é a imagem de Sseu destino. Ele testemunha uma violência que não apenas destrói um homem, mas que destruirá todos os homens. O interdito que se apossa dos outros à vista de um cadáver é o recuo em que rejeitama violência, em que se separam da violência (Bataille, 2013, p. 68, grifos no original).

O interdito da morte, segundo Bataille, é análogo a outros processos de restrição dos fenômenos ou organismos que podem contaminar o corpo humano. Desse modo, podemos deduzir que o interdito possui características similares à política do abjeto. $O$ mal-estar causado pela presença de um cadáver, em certo sentido, é comparável à relação que os sujeitos ocidentais desenvolveram com os fluidos corporais e a outros organismos vivos que são compreendidos como sujos ou impuros. No caso dos fluidos corporais, assim como o cadáver, também foram estabelecidos vários mecanismos de separação na cultura ocidental.

As separações entre o corpo e os fluidos corporais, por exemplo, foram capitaneadas por um projeto de civilização do comportamento humano, surgido gradativamente no início da modernidade europeia, como assinala o sociólogo alemão Norbert Elias no clássico livro O processo civilizador.

Para ilustrar essa similaridade entre o interdito e a política do abjeto, é exemplar a passagem em que Bataille afirma existir uma relação entre o nojo provocado pelo cadáver e aquele causado pelos fluidos corporais:

O horror que temos dos cadáveres é vizinho do sentimento que temos diante das dejeções alvinas de origem humana. Essa aproximação faz ainda mais sentido na medida em que temos um horror análogo aos aspectos da sensualidade que qualificamos de obscenos (Bataille, 2013, p. 81).
Apesar do processo de "civilização" dos costumes estar decantando há vários séculos na cultura ocidental, a relação entre o corpo e os fenômenos do abjeto é constantemente reafirmada pela moral vigente, pois o abjeto está na base da relação do corpo com os fluidos que dele emanam, assim como na relação entre os corpos que circulam no meio social. Entretanto, Bataille consegue vislumbrar a existência de brechas nos interditos, fazendo emergir as transgressões. Ele diz que "não há interdito que não possa ser transgredido" (Bataille, 2013, p. 87), pois a transgressão é frequentemente admitida ou até mesmo prescrita no próprio interdito.

Em síntese, o interdito e as transgressões estão associados diretamente. A transgressão existe a partir dos elementos que formam o interdito. $\mathrm{O}$ ato de transgredir uma norma ou conduta só é possível a partir dos referenciais elaborados pela interdição. Ou seja, a transgressão se dá na transformação dos valores morais que residem no interdito. No caso da transgressão provocada pelos fluidos corporais, por exemplo, a possibilidade de ruptura com a norma ocorre na inversão ou no abandono dela. Entretanto, a norma teve que ser identificada para que a transgressão fosse possível.

Nesse cenário, todavia, a transgressão dos interditos também está sujeita a regras que são intercambiáveis, por isso "não se trata de liberdade: em tal momento e até este ponto, isso é possível - esse é o sentido da transgressão" (Bataille, 2013, p. 89). Assim, as transgressões ocorrem em meio às exceções prescritas no interdito, sendo necessário compreender que há uma racionalidade lógica no processo de transgressão. Esse ponto será retomado quando acionarmos o conceito de profanação elaborado pelo filósofo italiano Giorgio Agamben (2007). 
De um modo geral, diante dos apontamentos apresentados por Julia Kristeva e Georges Bataille, podemos considerar que o conceito de abjeto está diretamente ligado ao corpo humano, bem como às emoções e aos dramas que causam medo, nojo e terror. Em que medida as imagens produzidas por Joel-Peter Witkin recorrem ao abjeto? E quais questões estão em jogo nas imagens por ele criadas? Além disso, quais saberes e poderes são mobilizados na produção das imagens do abjeto, particularmente naquelas geradas por este autor? Pretendemos discutir e aprofundar essas questões a partir da análise de três imagens produzidas pelo artista visual Joel-Peter Witkin.

\section{Joel-Peter Witkin:}

\section{profanador das fronteiras}

"Ele [o abjeto] é tudo que deve ser evitado, separado e até eliminado: o perigoso, o imoral e o obsceno entram na demarcação do fétido e do repugnante" (Fígari; Benitez, 2009, p. 23). Essa noção do conceito de abjeto apresentada pelos antropólogos Carlos Eduardo Fígari e Maria Elvira Diaz-Benítez demonstra o alcance do fenômeno da abjeção na cultura ocidental. Para discutir sobre o abjeto, porém, é imprescindível remontar os procedimentos históricos que constituíram a política de regulação dos corpos, a todo o conjunto de práticas que apontaram ao disciplinamento dos corpos na modernidade.

Na década de 1970, o filósofo francês Michel Foucault, em uma entrevista intitulada "Poder-Corpo", discorre sobre os diferentes processos de construção de saberes e práticas que atuavam nos corpos dos séculos XVIII e XIX. Nas palavras do autor, o corpo é um princípio de atuação do poder das sociedades modernas. Ele afirma que as práticas dirigidas aos corpos geravam categorizações e disciplinas, organizando um conjunto de conhecimentos sobre os corpos, as sexualidades e as práticas sociais. Foucault assinala a existência de uma transformação do poder em relação às sociedades monárquicas, dando atenção às técnicas de disciplina que passaram a assegurar a regulação do corpo social na modernidade. Essa transformação fica evidente quando ele afirma:

Não há um corpo da república. Em compensação, é o corpo da sociedade que se torna, no decorrer do século XIX, o novo princípio. É este corpo que será preciso proteger, de um modo quase médico: em lugar dos rituais através dos quais se restaurava a integridade do corpo do monarca, serão aplicadas receitas, terapêuticas como a alimentação dos doentes, o controle dos contagiosos, a exclusão dos delinquentes. A eliminação pelo suplício é, assim, substituída por métodos de assepsia: a criminologia, a eugenia, a eliminação dos degenerados (Fou cault, 1979, p. 145).

A análise foucaultiana nos permite entender que a modernidade construiu certas técnicas específicas para a regulação da presença do abjeto, tais como as práticas de contenção ou saneamento dos fatores biológicos que afetam às populações humanas e que o autor denominou "biopolíticas", operando a partir do reforço de interditos e da manutenção da política da abjeção. Com isso, é importante frisar que as técnicas de poder analisadas por Michel Foucault caracterizaram o período histórico da modernidade, e o próprio filósofo alerta que "o poder penetrou no corpo, encontra-se exposto no próprio corpo" (Foucault, 1979, p. 146). Assim sendo, o cor- po contemporâneo e as suas representações também estão ligados, de algum modo, aos exercícios de poder na cultura ocidental, embora não sejam exatamente os mesmos da era industrial estudada por Foucault.

A análise que desenvolveremos a seguir busca apresentar certos caracteres que compõem a presença do abjeto nas imagens de Joel-Peter Witkin. Seguindo a premissa de que o abjeto faz parte de um cenário cultural do Ocidente, que se esforçou por implementar diferentes técnicas disciplinares para "civilizar" os corpos e de seus fluidos, cabe pensar o que está em jogo quando o abjeto se instaura nessa imagem corporal.

Uma das intenções deste artigo é demonstrar como Witkin consegue criticar certas moralizações que vigoram em torno ao corpo contemporâneo, a partir do momento em que dá visibilidade àquilo que deveria estar escondido, separado, expurgado da imagem do corpo humano. Operando num projeto de transgressão das imagens do corpo, Witkin nos faz ver o caráter regulatório que governa os corpos, os gestos e as práticas culturais que enxugam o abjeto da carnalidade.

As três imagens que se seguem foram escolhidas para ser analisadas neste trabalho, pois elas tratam de evidenciar o cadáver, o ânus e o corpo sacrificado, respectivamente. Essas três temáticas possuem uma relação intrínseca com o abjeto e todos os procedimentos modernos que constituíram determinados valores higienistas e moralizadores da carne, do corpo e dos fluidos.

Um cadáver em estado de decomposição é um símbolo da abjeção. Em Myself as a dead clown, Joel-Peter Witkin expõe na imagem aquilo que comumente está ligado à contaminação, ao abjeto execrado do meio social. O título faz menção à personagem do palhaço, figura que permeia o imaginário da alegria e 


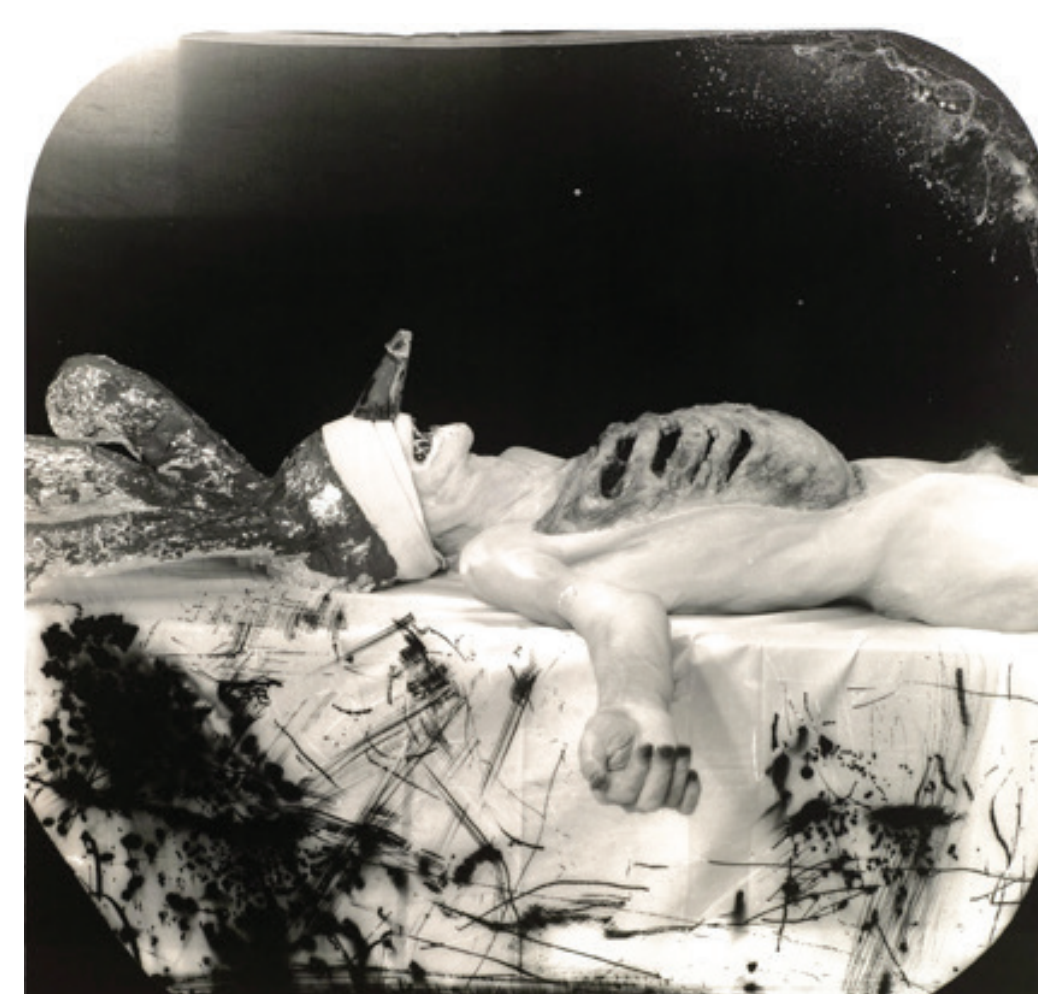

Figura 1: Joel-Peter Witkin, 2007.

da felicidade, com um vitalismo que arranca sorrisos e gargalhadas. Apesar disso, o artista visual ressignifica o que seria um palhaço ao apresentar um corpo em seu estado de precariedade, ao revelar o vazio do corpo sem vida, ao demonstrar a morte e a violência da carne putrefata. Entre as características que compõem a imagem, há de se mencionar o terror causado pelas fissuras na pele, pela boca entreaberta, pelas vias que dão acesso a um mundo nefasto e perigoso - o universo do abjeto.

A representação do corpo em Myself as a dead clown dissemina o pavor, expõe aquilo que deveria ser expurgado; e, com isso, demonstra que o nojo é um dos elementos que fundam as interdições, pois o caráter de inadmissibilidade do abjeto revela toda a potência de um excesso que pretendemos excluir constantemente. De acordo com Bataille, esquivamo-nos da corrupção da carne morta através dos sentimentos de repulsa:

O poder de engendrar da putrefação é uma crença ingênua que corresponde ao horror mesclado de atração que ela desperta em nós. Essa crença está na base de uma ideia que tivemos da natureza, da natureza má, da natureza que envergonha: a corrupção resumia esse mundo de que surgimos, e a que retornaremos: nessa representação, o horror e a vergonha se ligavam ao mesmo tempo a nosso nascimento e morte (Bataille, 2013, p. 80).

Witkin nos dá a visibilidade da putrefação da carne ao mostrar um corpo destituído de vida. Nessa operação, ele trabalha com o abjeto em seus elementos mais convencionais: o nojo e o medo.

Passando, agora, para a segunda imagem de nossa breve análise, o artista traz à tona uma representação do corpo desnudo. Apesar de apresentar o corpo nu, porém, Witkin produz uma cena capaz de questionar os entendimentos assentados sobre o corpo e a sexualidade na cultura contemporânea.

A fotografia Man reflected traz a imagem de um corpo masculino mostrando o pênis e as nádegas, regiões do corpo consagradas para o exercício da sexualidade. A ambivalência da imagem, contudo, joga também com referências diretas que remetem à abjeção. Em Man reflected, Witkin demonstra o desconforto que um corpo sexuado causa ao desordenar as fronteiras dos gêneros. Ao dar a ver as "partes baixas" do corpo, a imagem ganha uma dimensão abjeta mais articulada, sendo explo- radas em primeiro plano as nádegas, aquilo que comumente é escondido do espaço público.

As genitálias foram, desde muito tempo na cultura ocidental, capturadas pelos interditos sexuais que fabricaram discursividades e sentidos ligados à vergonha, ao nojo e ao medo. A estratégia de visibilidade em relação às partes baixas do corpo remonta à estética da arte grotesca da Idade Média, como relata o filósofo russo Mikhail Bakhtin.

Depois do ventre e do membro viril, é a boca que tem o papel mais importante no corpo grotesco, pois ele devora o mundo; e em seguida o traseiro.

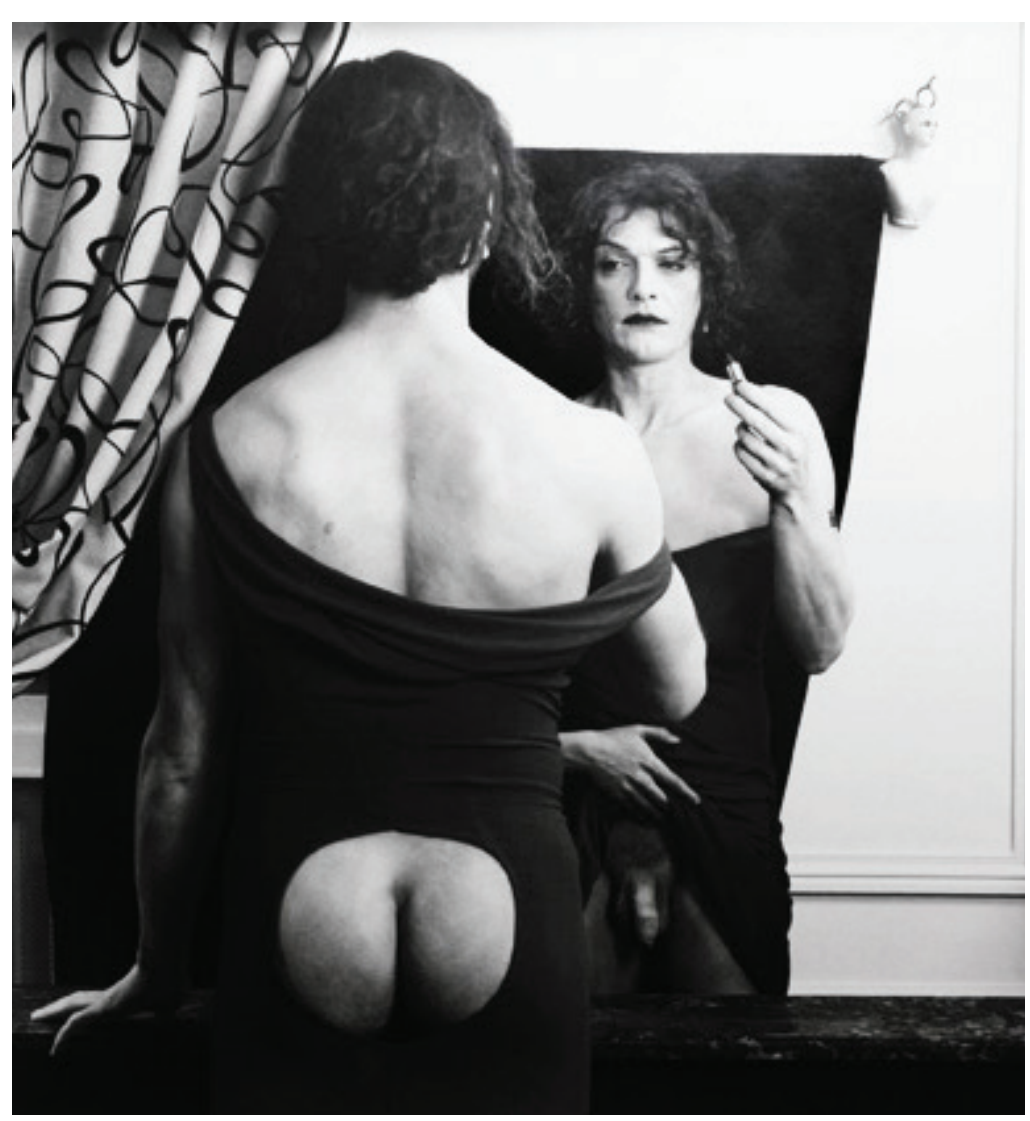

Figura 2: Joel-Peter Witkin, 2007 
Todas essas excrescências e orifícios caracterizam-se pelo fato de que são o lugar onde se ultrapassam as fronteiras entre dois corpos e entre o corpo e o mundo, onde se efetuam as trocas e as orientações recíprocas (Bakhtin, 2013, p. 277, grifos no original).

A estética do corpo grotesco medieval era configurada por noções que diferem do que entendemos por corpo na contemporaneidade. Diante disso, é importante entender que na Idade Média o corpo grotesco evidenciava uma cosmologia pautada na comunicação do corpo aberto com o mundo das coisas e da natureza, fenômeno que deixa de existir na modernidade. Os dispositivos da modernidade, na perspectiva apresentada por Foucault - conjunto de discursos, práticas, saberes, instituições e representações - possibilitaram o desenvolvimento dos valores de uma sociedade burguesa e heterossexual, executando um processo de abjeção dos corpos e sexualidades que não se enquadravam nas normas que naturalizaram a sexualidade.

A política da abjeção, no âmbito da sexualidade, produziu zonas de legitimidade em determinados órgãos do corpo, destinando ao traseiro/ânus a função de excretar, expulsar os dejetos. Nesse sentido, o ânus tornou-se um lugar de vigilância e disciplina higiênica ou moral. É por esse motivo que há uma nítida construção de terror ao privilegiar o que foi retirado da esfera do prazer sexual.

$O$ terror anal, em certo sentido, se manifesta na recusa da castração do ânus, pois ele, quando aberto, não demarca os gêneros (gender). Essa é a aposta da filósofa espanhola Beatriz Preciado. Os discursos que recaem sobre as práticas sexuais anais castraram o ânus, pro- duziram barreiras sociais e simbólicas em torno dessa parte do corpo. Assim, o fechamento e o saneamento constante do ânus fazem parte do sistema que assegura o regime político da heterossexualidade. Como afirma a própria autora:

No homem heterossexual, o ânus, entendido unicamente como orifício excretor, não é um órgão. É a cicatriz que marca a castração do corpo. O ânus fechado é o preço que o corpo paga para o regime heterossexual pelo privilégio da sua masculinidade (Preciado, 2009, p. 136-137) ${ }^{3}$.

Witkin questiona o regime da heterossexualidade, a partir do momento em que dá visibilidade ao corpo visualmente transgenerificado mostrando o traseiro como parte de uma identidade sexual. Além disso, ele propõe uma paródia de gênero na imagem. O gênero é demonstrado como performance que não precisa ter linearidade entre corpo e sexo. De certo modo, essa imagem faz uma paródia dos modelos corporais e questiona o binômio tradicional, bem como as fronteiras e as normas sexuais e de gênero.

A terceira imagem da nossa análise remete ao interdito do sagrado. Em Naked follow the naked Christ, o artista reproduz uma imagem recorrente na simbologia cristã: o corpo flagelado de Jesus Cristo. Apesar disso, ele propõe vários deslocamentos de sentido na configuração simbólica que envolve essa representação. Atingindo diretamente o sentido de sagrado, Witkin aproxima o corpo sagrado - princípio fundamental para o reconhecimento da sacralidade - do corpo humano mundano. Partindo de uma perspectiva que questiona o corpo sagrado, as imagens de Witkin realizam uma operação

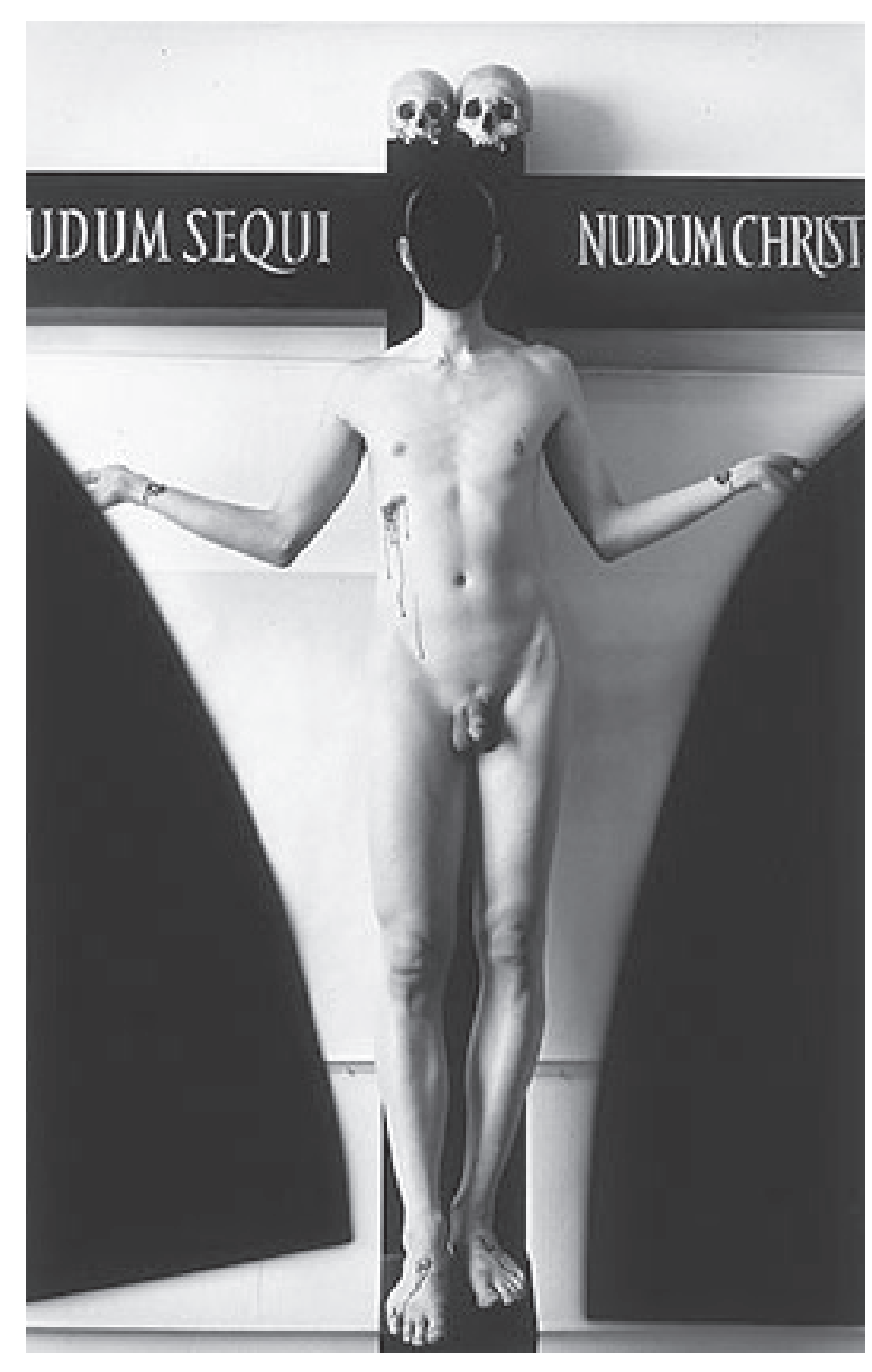

Figura 3: Joel-Peter Witkin, 2007.

de transgressão do princípio do corpo intocável das divindades. As barreiras que separam o mundo dos corpos sacralizados dos corpos profanos são questionadas, a ponto de restituir a carnalidade do corpo sagrado. 
$\mathrm{Na}$ imagem projetada em Naked follow the naked Christ, o abjeto utilizado por Witkin perturba a ordem, desafia a lei e questiona a cosmologia cristã. Parodiando a sacralidade da imagem do Cristo crucificado, o artista elabora uma crítica à religião católica e também às normas cristãs que resguardavam os corpos. Com dizeres em latim, Nudum Sequi Nudum Christu (Nu para o Cristo nu), Witkin propõe o desnudamento do corpo sagrado, o corpo santo de Cristo.

Esta imagem aproxima a santidade da carnalidade humana e escancara as brechas que existem na intrínseca relação entre os interditos e as transgressões religiosas. Para Bataille, a imagem do sacrifício de Cristo traz todo o teor da transgressão do interdito do assassinato, um dos principais interditos formadores da sociabilidade humana. O mandamento religioso "não matarás!" é violado em um ato sangrento de transgressão prescrita em outras esferas da vida comum. O corpo imolado, crucificado, torna-se um símbolo destituído da transgressão que violou o interdito do assassinato. Seguindo esse raciocínio, Bataille explica que "o essencial é que, na ideia do sacrifício da Cruz, o caráter de transgressão é deformado", e conclui do seguinte modo: "esse sacrifício é por certo um assassinato, ele é sangrento" (Bataille, 2013, p. 113).

A simbologia cristã conseguiu destituir todo o teor de transgressão que existe na imagem da crucificação de Cristo, houve um desprendimento do corpo do Cristo, uma elevação espiritual que sacralizou a imagem do Cristo crucificado. O filósofo italiano Giorgio Agamben explica como se deu esse processo de sacralidade dos símbolos religiosos. "Sagradas ou religiosas eram as coisas que de algum modo pertenciam aos deuses", afirma esse autor. "Como tais, elas eram subtraídas ao livre uso e ao comércio dos homens", continua Agamben, "não podiam ser vendidas nem dadas como fiança, nem cedidas em uso fruto ou gravadas em servidão" (Agamben, 2007, p. 65).

Em outras palavras, houve uma supressão da humanidade do corpo de Cristo. Na cruz, ele foi consagrado (consecratus) como divino, tornou-se literalmente um deus, tendo apagado o teor do ato de transgressão humana que culminou na crucificação - a imagem de um corpo morto e flagelado. Essa explicação ganha força quando Bataille afirma que "o sacrifício, se é uma transgressão voluntária, é a ação deliberada cujo fim é a súbita transformação do ser que é sua vítima" (Bataille, 2013, p. 114).

Assim, utilizando a imagem consagrada do Cristo crucificado, Witkin busca restituir a humanidade que existe no corpo Cristo. $\mathrm{O}$ desnudar do interdito religioso acontece quando o artista inscreve um paralelo entre o corpo sacro de Cristo e o corpo perecível da humanidade. O trabalho de despir o corpo de Cristo institui um processo de erotização do corpo outrora sagrado. Dessa forma, ao nivelar a santidade da imagem de Cristo à carnalidade humana (corruptível, por sinal), Witkin profana a sacralidade cristã. $\mathrm{O}$ ato de profanar, como explica Giorgio Agamben, é um jogo simbólico que devolve à humanidade aquilo que foi separado da esfera comum, ordinária e usual. É por esse motivo que: "a profanação implica, por sua vez, uma neutralização daquilo que profana". De acordo com Agamben, ainda, "depois de ter sido profanado, o que estava indisponível e separado perde a sua aura e acaba restituído ao uso" (Agamben, 2007, p. 68)

Witkin produz uma imagem carregada de profanação ao restituir Cristo à humanidade, produzindo uma paródia que joga com o caráter profanatório do abjeto. A abjeção provocada pela imagem do corpo nu crucificado é negociada pelo elogio da carnalidade, não esquecendo que a carne está diretamente ligada, em um plano geral, aos discursos religiosos do pecado, da corrupção, do aniquilamento que envergonha e repulsa, ao abjeto. Como nos diz Bataille: "[...] a carne é a expressão de retorno dessa liberdade ameaçadora" (Bataille, 2013, p. 116).

\section{Considerações sobre o profanar do} abjeto na imagem contemporânea

A breve análise de algumas imagens do corpo abjeto produzidas pelo artista visual Joel-Peter Witkin nos permitiu identificar alguns deslocamentos realizados pela presença do abjeto na imagem. A partir de agora, na tentativa de fechar este percurso, é necessário trazer algumas considerações sobre a circulação dessas imagens na atualidade, no intuito de compreender quais são as mobilizações realizadas pela presença do abjeto nas imagens do corpo contemporâneo.

A imagem do corpo consagrada pela modernidade foi sedimentada por um conjunto heterogêneo de discursos, práticas, representações, imagens e, principalmente, sensações dirigidas ao corpo. A modernidade, segundo Foucault, consolidou os dispositivos de saber e poder que atuavam na regulação das subjetividades que suscitavam no corpo os discurso médico, religioso, moral, jurídico e artístico.

As sociedades disciplinares dos séculos XVIII e XIX, como assinala esse mesmo autor, implementaram dispositivos que conformavam os corpos visando a canalizar produtivamente sua vitalidade. Paralelamente ao fenômeno da disciplina, certamente, a produção discursiva e imagética sobre o abjeto também foi se desenvolvendo. O processo de disciplinamento dos corpos, na modernidade, não expeliu completamente o abjeto, pois a abjeção faz parte dos próprios discursos médicos, 
higienistas, artísticos, sexuais e morais que vigoravam nos séculos passados, chegando com vigor até a contemporaneidade.

Em suma, o corpo disciplinado e o corpo abjeto fazem parte de um complexo jogo que envolve a vida e a morte, a natureza e a cultura, o humano e as aberrações. Por ser um fenômeno que ultrapassa os limites das normas sociais, o abjeto produz imagens que desafiam os dispositivos de poder que apontam para o disciplinamento dos corpos, as relações corpóreas e as imagens corporais no decorrer da história.

Nesse sentido, o historiador da arte italiano Umberto Eco ilustra a presença do abjeto sendo atravessado por um conjunto de enunciados presentes nas imagens do corpo enfermo da modernidade:

O fascínio pela doença afirma-se igualmente nas artes figurativas, seja quando o artista representa, idealizando-o, o exausto abandono de uma beleza às portas da morte ou o lento discurso de uma enfermidade, seja quando representa de maneira realista os excluídos da sociedade (Eco, 2007, p. 302).

Diante do que apresenta esse autor na passagem anterior, fica evidenciado, em certa medida, que os dispositivos modernos que disciplinavam os corpos se ocupavam em executar os enunciados e práticas de exclusão do abjeto no meio social. O sanitarismo, a medicina legal e forense, as políticas públicas de regulação social, os confinamentos na prisão e na escola evidenciavam uma separação de tudo aquilo que viesse contaminar o corpo social. Isso quer dizer que as técnicas de disciplina e regulação dos corpos pretendiam expurgar os fluidos corporais e tudo que trouxesse à tona o abjeto.

A configuração do abjeto, por sua vez, continua fazendo parte dos jogos de poder que envolviam os impulsos de domesticação e bestialização propagados pelas tecnologias da sociedade disciplinar. Apesar disso, aquilo que incomoda, excede e envergonha - o abjeto - se configura como elemento significativo de questionamento dos mecanismos de poder que atuam nos corpos da sociedade contemporânea.

Resumidamente, as imagens do corpo abjeto produzidas por Joel-Peter Witkin se configuram como experiências que desafiam os dispositivos de poder da contemporaneidade, com herdeiros da moral moderna e seus ímpetos disciplinares e civilizadores. Es sas imagens, assim como outras que recorrem à estética do abjeto, operam uma profanação capaz de produzir subjetividades que contestem as imagens hegemônicas dos corpos disciplinares que circulam nas artes e nas mídias contemporâneas.

Para finalizar, cabe citar uma ideia-síntese que compartilhamos do psicanalista Félix Guatarri:

A subjetividade permanece hoje massivamente controlada por dispositivos de poder e de saber que colocam as inovações técnicas, científicas e artísticas a serviço das mais retrógradas figuras da socialidade. E, no entanto, é possível conceber outras modalidades de produção subjetiva - estas processuais e singularizantes. Essas formas de reapropriação existencial e de autovalorização podem tornar-se amanhã, a razão de viver de coletividades humanas e de indivíduos que se recusam a entregar-se à en- tropia mortífera, característica do período que estamos atravessando (Guatarri, 1993, p. 190-191).

Em 1993, Félix Guatarri apontava para a existência de práticas sociais, culturais e artísticas capazes de jogar contra os dispositivos contemporâneos de poder. Essas práticas seriam capazes de mobilizar forças com a potência de questionar as normas, as fronteiras e as disciplinas que moldaram as imagens do corpo na modernidade. Nesse sentido, identificamos que Joel-Peter Witkin utiliza a profanação do corpo, por meio da visibilidade da abjeção, como forma de questionar os dispositivos de poder que atuam nos corpos da contemporaneidade, crescentemente construídos como as imagens lisas e polidas irradiadas pelos meios de comunicação, ao mesmo tempo em que questiona as dicotomias e classificações que caracterizavam os corpos produzidos pelo poder disciplinar das sociedades industriais.

Reinstituindo o abjeto ao uso comum da humanidade, por meio da visualidade do obsceno, do impuro e do excesso, Witkin nos propõe um jogo onde todos podem provocar e ser provocados pelo abjeto. E é nesse jogo que novas articulações entre política, arte, corpo e vida podem ser traçadas.

\section{Referências}

AGAMBEN, Giorgio. Profanações. São Paulo: Boitempo, 2007.

BATAILLE, Georges. 0 erotismo. Belo Horizonte: Autêntica, 2013. 
BAKHTIN, Mikhail. A cultura popular na Idade Média e

no Renascimento: o contexto de François Rabelais. São Paulo: HUCITEC; Brasília: Universidade de Brasília, 1993.

ECO, Umberto. História da feiúra. São Paulo: Record, 2007.

FÍGARI, Carlos Eduardo; DÍAZ-BENÍTEZ, Maria Elvira. Sexualidades que importam: Entre a perversão e a dissidência. In: Prazeres dissidentes. Rio de Janeiro: Garamond Universitária, 2009. p. 21-29.

FOUCAULT, Michel. Poder-corpo. In: Microfísica do poder. Rio de Janeiro, Graal, 1979.

GUATARRI, Félix. Da subjetividade. In: PARENTE, André (org.). Imagem-máquina: A era das tecnologias do virtual. Rio de Janeiro: Ed.34, 1993.

KRISTEVA, Julia. Poderes de la perversión. Buenos Aires: Siglo XXI editores, 1989.

PRECIADO, Beatriz. Terror anal. In: HOCQUNGHEM, Guy.

El deseo homosexual. Barcelona: Melusina, 2009.

\section{Notas}

1 Mestre em Comunicação pelo Programa de Pós-graduação em Comunicação da Universidade Federal Fluminense (PPGCOM/UFF). Rua Tiradentes, 148, Ingá, Niterói/RJ, 24210-510. CEP: 20540-090. E-mail: sanches.julius@gmail.com.

2 "El cadáver - visto sin Dios y fuera de La ciencia - es el colmo de la abyección. Es la muerte infestando la vida".

3 Tradução do autor do original: "En el hombre heterosexual, el ano, entendido únicamente como orificio excretor, no es un órgano. Es la cicatriz que deja en el cuerpo la castración. El ano cerrado es el precio que el cuerpo paga al régimen heterosexual por el privilegio de su masculinidad". 